SVU- International Journal of Veterinary Sciences, 3 (1): 27-38, 2020.

Print ISSN: 2535-1826

\title{
Effect of Prebiotic on the Behavioural Patterns, Performance, Carcass Characteristics, Antibody Titer and Some Blood Parameters of Mule Ducks
}

\section{Usama T. Mahmoud', Rasha I.M. Hassan², Omar Amen³, Ghada S.E. Abdel-Raheem², Diya Al-Rammamneh ${ }^{4}$}

${ }^{1}$ Department of Animal Hygiene, ${ }^{2}$ Departments of Animal and Clinical Nutrition, ${ }^{3}$ Department of Poultry Diseases, Faculty of Veterinary Medicine, Assiut University 71515, Egypt, ${ }^{4}$ Department of Biology, Faculty of Tayma, Tabuk University, 71491, Tabuk, KSA

\begin{abstract}
This study was conducted to investigate the effects of dietary supplementation of prebiotic on behavioural patterns performance and some blood parameters of ducks. A total of forty-eight 15 days-aged ducks (Mule) were randomly allotted to three dietary treatments containing 0 (Control), $1.5 \mathrm{~g} / \mathrm{kg}$ and $3.0 \mathrm{~g} / \mathrm{kg}$ prebiotic, respectively. The results indicated that using prebiotic as a feed additive at a dose of $1.5 \mathrm{~g} / \mathrm{kg}$ effect on duck movement activities as it increased walking and standing activities, while it reduced the resting behavioural activities. Further, regarding the ingestive behaviour, both 1.5 and $3.0 \mathrm{~g} / \mathrm{kg}$ prebiotic addition increased the feeding activities, while, only adding $3.0 \mathrm{~g} / \mathrm{kg}$ prebiotic increased the drinking activities in comparison to the control. Moreover, the result indicated that prebiotic did not affect preening activities. Moreover, the inclusion of prebiotic at 1.5 or $3.0 \mathrm{~g} / \mathrm{kg}$ caused numerical improvement in all measured performance parameters (i.e. body weight, weight gain, feed consumption, feed conversion ratio, caloric conversion ratio, and performance index). The $3.0 \mathrm{~g} / \mathrm{kg}$ level of prebiotic induced significant decreased in serum cholesterol and both 1.5 and $3.0 \mathrm{~g} / \mathrm{kg}$ prebiotic increased the HI titer of Avian influenza vaccine. In conclusion, prebiotic supplementations up to $0.30 \mathrm{~g} / \mathrm{kg}$ diet show a non-significant positive effect on duck growth performance. However, the behavioural and haematological responses of duck to prebiotic supplementation are needed to be carefully considered.

Keywords: Duck, Prebiotic, Behavior, Performance, Blood Parameters
\end{abstract}

DOI: $10.21608 / \mathrm{svu} .2019 .16763 .1028$

Received: September 17, $2019 \quad$ Accepted: December 6, $2019 \quad$ Published: December 6, 2019 *Corresponding Author: Rasha I. M. Hassan E-mail: rasha_feeding@yahoo.com

Citation: Mahmoud et al., Effect of Prebiotic on the Behavioural Patterns, Performance, Carcass Characteristics, Antibody Titer and Some Blood Parameters of Mule Ducks. . SVU-IJVS 2020, 3 (1): 27- 38 .

Copyright: (C) Mahmoud et al., This is an open access article distributed under the terms of the creative common attribution license, which permits unrestricted use, distribution and reproduction in any medium provided the original author and source are created.

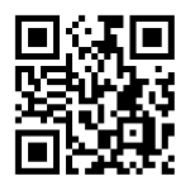

Competing interest: The authors have declared that no competing interest exists. 


\section{Introduction}

Ducks have an essential role as meat and egg producing poultry in Egypt. Egypt is a relevant "duck country" there are likely between 30 and 55 million ducks in the backyard sector, plus nearly 5 million ducks in commercial farms (Hogerwerf and Sidding, 2007). The duck sector in Egypt is the following in rank after the chicken sector; $46 \%$ of family producers, who have any poultry, will have ducks (Ali et al., 2011). The mule ducks are sterile intergeneric hybrids resulted from the mating between male Muscovy ducks and female common ducks (Anus plutyrhynchos), (El-Sayed and Mahrous, 2013). The Mule duck is famous due to its attractive marbled meat which makes for special delicacy. This genotype differs from the domestic duck in many respects, especially in the lower fat content of the body and in the meat quality.

Modifications of diet are one among the most preferred and practical ways to improve the productivity in poultry. Mannan-Oligosaccharides (MOS) and BGlucans are components of yeast cell walls. MOS include proteins, glucans and phosphate radicals as well as mannose (Klis et al., 2002). MOS proteins have relatively high proportions of serine, threonine, aspartic and glutamic acids, and a paucity of methionine (Song and $\mathrm{Li}, 2001$ ). $\beta$ glucans is a heterogeneous group of glucose polymers, research work in humans and rats stated that $\beta$-glucans reduced the harmful physiological and metabolic changes induced by oxidative stress conditions through down-regulation of c-fos and c-jun expression in brain tissue and reactive oxygen species activities (Saluk et al., 2013, Hong et al., 2014)

Recently, MOS and $\beta$-glucans prebiotic has received much attention as a dietary supplementation for promoting production and health in various animals including cattle and chickens (Koksal et al.,
2013, Uyeno et al., 2015, Mahmoud et al., 2017). In poultry, MOS and the $\beta$-glucans combination have been used as immunestimulant and antioxidant to prevent ochratoxicosis and to treat chicken immune dysfunction (Awad et al., 2009). As well, it used for reducing the adverse effects of delayed feed access on growth rate in broiler chickens (Koksal et al., 2013). The addition of prebiotic to the feed of Pekin ducklings increased live weight with 4.94 $\%$ in males and with $4.67 \%$ in female, and improved the feed conversion ratio; due to the positive effect of the prebiotic on the healthy digestive microflora of birds, and the microbicide effect resulting in better utilization of feed, and an improvement in the poultry health, growth, and welfare (Gerzilov et al., 2011).

Currently, MOS and the $\beta$-glucans combination are being produced commercially for their potential prebiotic effects, especially as growth promoters. Even though reports concerning the significance of MOS and $\beta$-glucans combination in poultry are gaining popularity, still little is known of its ability to improve the duck health status and performance.

Thus, this study investigated the possible effect of a specific combination of MOS and $\beta$-glucans (AGRIMOS $®$ ) obtained from the yeast cell wall of Saccharomyces cerevisiae on behavior of Mule ducks, aiming to evaluate the effects of AGRIMOS® dietary supplementation as a new feeding strategies to improve duck production as it has limited scientific bases aiming to determine its advantages and disadvantages and get more information about it to guide the duck farmers either to go for application or no.

\section{Materials and Methods}

\section{Ethics statement}

All procedures and protocols were agreed by the Faculty of Veterinary Medicine Assiut University, Egypt. 
2.Mannan-Oligosaccharides and $\beta$ Glucans Combination

MOS and $\beta$-glucans prebiotic market product AGRIMOS $^{\circledR}$ was obtained from LALLEMAND SAS Co. (19 Rue des Briquetiers, 31702 Blagnac Cedex, France), distributed by Egavet Co., Egypt.

\section{Birds and Husbandry}

A total of forty-eight 15 days-aged ducks (Mule) were obtained from a local hatchery El Rehab, El Waelday St. Assiut, Egypt. Each bird was received the oilemulsified inactivated A/chicken/Mexico/232/94 (H5N2) vaccine (vaccine virus titer: 108.5 EID 50 or 256 HAU/dose) at the $15^{\text {th }}$ day of age. The birds were randomly assigned to 12-floor pens (1× $1 \mathrm{~m}$ per pen) in the same room at the Faculty of Veterinary Medicine Hospital. Wood shavings (5-cm depth) were used as litter. Temperatures and humidity were measured every 4 hours by using wall mount thermohydrometer which was fixed $30 \mathrm{~cm}$ above the litter surface. All ducks groups were fed diets as shown in Table 1 formulated according to the requirements proposed by the NRC (1994).

\section{Experimental Design}

At 15th d of age, the forty-eight birds were assigned based on body weight similarity to three experimental groups. Each treatment involved 4 replicates with four birds in each replicate. The experimental groups included a control group with a basal diet used in duck feeding. The remaining groups received an additional to basal diet AGRIMOS ${ }^{\circledR} \quad 1.5 \mathrm{~g} / \mathrm{kg}$ and $3.0 \mathrm{~g} / \mathrm{kg}$, respectively as shown in Table 1 .

*Each $2.5 \quad \mathrm{~kg}$ contains Retinol: 3.5mg; Cholecalciferol :0.05mg; $\alpha$ - tocopherol: $10 \mathrm{~g}$; Menadione: $2 \mathrm{~g}$; Thiamin: 1g; Riboflavin: $5 \mathrm{~g}$; pyridoxine: $1.5 \mathrm{~g}$; Cyanocobalamin: 10g;Nicotinic acid: 30g; Pantothenic acid: $10 \mathrm{~g}$; Folic acid: $1 \mathrm{~g}$; Biotin: $50 \mathrm{~g}$; Choline chloride: 250g; Iron: 30g; Copper: 10g; Zinc: $50 \mathrm{~g}$; Manganese: $60 \mathrm{~g}$; Iodine: $1 \mathrm{~g}$; Selenium: $0.1 \mathrm{~g}$.
Table 1. Main ingredients and nutrient composition of the experimental diets fed to broiler ducks from 15 to 60 days of age.

\begin{tabular}{lccc}
\hline \multirow{2}{*}{ Ingredients $(\mathrm{g} / \mathrm{kg})$} & \multicolumn{3}{c}{ Prebiotic treatments } \\
\cline { 2 - 4 } & $0 \mathrm{~g} / \mathrm{kg}$ & $1.5 \mathrm{~g} / \mathrm{kg}$ & $3.0 \mathrm{~g} / \mathrm{kg}$ \\
\hline Yellow corn & 582.0 & 580.5 & 579.0 \\
Soybean meal & 184.5 & 184.5 & 184.5 \\
Wheat bran & 150.0 & 150.0 & 150.5 \\
Sunflower oil & 51.5 & 51.5 & 51.5 \\
Prebiotic & -- & 1.5 & 3.0 \\
Limestone, ground & 13.0 & 13.0 & 13.0 \\
Sodium phosphate dibasic & 13.0 & 13.0 & 13.0 \\
Common salt & 3.0 & 3.0 & 3.0 \\
Premix* & 3.0 & 3.0 & 3.0 \\
& & & \\
Calculated composition & & & \\
ME $(\mathrm{MJ} / \mathrm{kg})$ & 12.5 & 12.5 & 12.5 \\
Crude protein $(\mathrm{g} / \mathrm{kg})$ & 160.1 & 159.9 & 159.8 \\
Methionine $(\mathrm{g} / \mathrm{kg})$ & 3.0 & 3.0 & 3.0 \\
Lysine $(\mathrm{g} / \mathrm{kg})$ & 9.1 & 9.1 & 9.1 \\
Calcium $(\mathrm{g} / \mathrm{kg})$ & 6.0 & 6.0 & 6.0 \\
Available phosphorus $(\mathrm{g} / \mathrm{kg})$ & 3.0 & 3.0 & 3.0 \\
\hline
\end{tabular}

\section{Behaviour observation}

The birds' behavioural patterns were observed according to the predefined ethogram (Table 2) using the instantaneous scanning sampling method at $10 \mathrm{~min}$. Interval per hour (Altmann, 1974) twice a day from 08:00 to 09:00 and from 14:00 to 15:00, for three days weekly (From Monday to Wednesday) during the entire experiment (From 15 to 60 days of age). To avoid interrupting bird behaviour, all observations were made from outside of the pens with a distance of $1.5 \mathrm{~m}$ and by single experienced persons. Behaviour was scanned 12 times each day (i.e. each pen scored six times/hr). Data are presented as the proportion of each behavioural frequency "number of scans out of the total number possible" (Mahmoud et al., 2015).

\section{Performance of ducks}

Body weight and feed intake were recorded every two weeks during the experiment. Body weight gain, feed conversion ratio, caloric conversion ratio (kcal ME consumed / g gain) and growth performance index as live body weight $(\mathrm{kg})$ / FCR X 100 were calculated. 
Table 2. Behavioural Ethogram used in the live observation of broiler ducks from 15 to 60 days of age.

\begin{tabular}{ll}
\hline $\begin{array}{l}\text { Behavioural } \\
\text { patterns }\end{array}$ & \multicolumn{1}{c}{ Definition } \\
\hline Standing & $\begin{array}{l}\text { Both feet are in contact with the floor, but no } \\
\text { other body part is in contact with the floor. } \\
\text { Most of the ventral region of the bird's body } \\
\text { in contact with the floor. Although no space } \\
\text { is visible between the floor and the bird. } \\
\text { The bird is in the process of taking multiple } \\
\text { steps. }\end{array}$ \\
Walking & $\begin{array}{l}\text { Bird's head is located inside the feeder. } \\
\text { Bird's beak is in contact with the drinker. } \\
\text { Gently pecking or scratching its feathers. }\end{array}$ \\
$\begin{array}{l}\text { Feeding } \\
\text { Prinking }\end{array}$ & $\begin{array}{l}\text { Pecking on the non-edible object (ground, } \\
\text { letter, walls). }\end{array}$ \\
\hline
\end{tabular}

\section{Carcass traits}

At the end of the experiment, two birds from each replicate were randomly selected and weighed live, slaughtered by neck cut and allowed to bleed. Afterwards, the birds were scalded, de-feathered and carcasses were eviscerated. The weight of carcass, gizzard, heart, liver, spleen, bursa and thymus were taken, and data were expressed as the relative weight of live body weight.

\section{Blood parameters and Avian influenza vaccine titer}

Blood samples were collected from 12 birds each group at 60th day of age. Sample collection and processing were done using proper personal protective equipment (PPE). Serum was separated by centrifugation at $3000 \mathrm{rpm}$ for $10 \mathrm{~min}$ and stored at $-18{ }^{\circ} \mathrm{C}$ until analysis. A) Total protein and its fractions (albumin and globulin) and cholesterol were determined by spectrophotometer using commercial test kits (Spectrum, Cairo, Egypt). b) Hemagglutination inhibition (HI) assay of Avian influenza vaccine was performed as previously described (World Health Organization, 2002). Briefly, serum samples were first inactivated for $30 \mathrm{~min}$ at $56{ }^{\circ} \mathrm{C}$. Serial two-fold dilutions of serum samples were then incubated with four units of homologous A/chicken/Mexico/232/94 (H5N2) antigen at $37{ }^{\circ} \mathrm{C}$ for one h. Twentyfive microliters of $1 \%$ chicken red blood cells (CRBC) were then added and incubated at room temperature for $45 \mathrm{~min}$. The HI titer was defined as the reciprocal of the highest dilution of serum which ultimately prevented the agglutination of CRBC.

\section{Economic efficiency}

Feed cost was calculated by feed intake, cost of the basal diet and the prices of feed additives. The economic efficiency was expressed as a percent of net revenue/ feed cost.

\section{Statistical Analysis}

The data were analysed by one-way analysis of variance using the general linear model procedures of SPSS 16.00 Software (SPSS Inc., Chicago, IL, USA); significance was designated as $\mathrm{P} \leq 0.05$. Means were compared by Tukey's test when a significant difference was detected.

\section{Results}

\section{Bird behaviors}

\subsection{Inactivity - resting}

The resting activities of birds are presented in figure 1 . The results clarified that dietary supplementation with $1.5 \mathrm{~g} / \mathrm{kg}$ prebiotic significantly $(P \leq 0.05)$ decreased resting activity compared to the control group. In contrast, the supplementation of the diet with $3.0 \mathrm{~g} / \mathrm{kg}$ prebiotic did not affect resting activities compare to control.

\subsection{Mobility behaviours}

The overall relationships between prebiotic treatments and mobility behaviours, including standing and walking presented in figure 1, shown that dietary supplementation with $1.5 \mathrm{~g} / \mathrm{kg}$ prebiotic significantly $(P \leq 0.05)$ increased the walking and standing activities of the birds in comparison to the control group. In contrast, the supplementation of the diet with $3.0 \mathrm{~g} / \mathrm{kg}$ prebiotic did not affect walking and standing activities of the birds compared to control. 


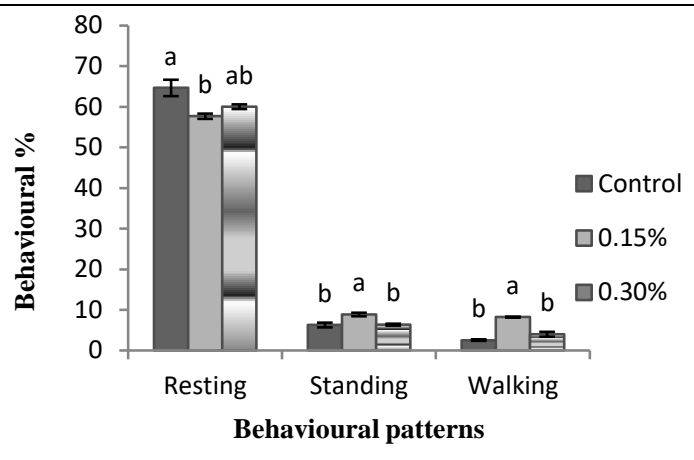

Figure 1. The effects of different prebiotic supplementation $(0,1.5$, and $3.0 \mathrm{~g} / \mathrm{kg})$ on mobility and resting behavioural activities of broiler ducks, (Means \pm SE represent the percentage activities of all birds per pen). a,b Columns with no common superscript differ significantly $(P<0.05)$.

\subsection{Nutritive behaviours}

Results presented in figure 2 showed that both $1.5 \mathrm{~g} / \mathrm{kg}$ and $3.0 \mathrm{~g} / \mathrm{kg}$ prebiotic significantly increased feeding activity than the control group. While drinking activity was only significantly $(P \leq 0.05)$ increased in the $3.0 \mathrm{~g} / \mathrm{kg}$ groups in comparison to the control group.

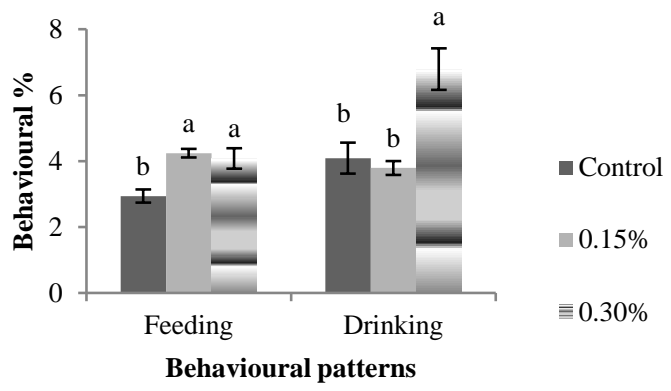

Figure 2. The effects of different prebiotic supplementation $(0,1.5$, and $3.0 \mathrm{~g} / \mathrm{kg})$ on nutritive behaviour activities of broiler ducks, (Means \pm SE represent the percentage activities of all birds per pen). a,b Columns with no common superscript differ significantly $(\mathrm{P}<0.05)$.

\subsection{Comfort behaviours}

The effect of prebiotic on comfort behaviours was presented in figure 3 . Results showed that both $1.5 \mathrm{~g} / \mathrm{kg}$ and 3.0 $\mathrm{g} / \mathrm{kg}$ prebiotic not affected duck preening activities in comparison to control. While, only $3.0 \mathrm{~g} / \mathrm{kg}$ prebiotic significantly increased the leg stretching activities, but the $1.5 \mathrm{~g} / \mathrm{kg}$ prebiotic not significantly increased the leg stretching activities in comparison to control.

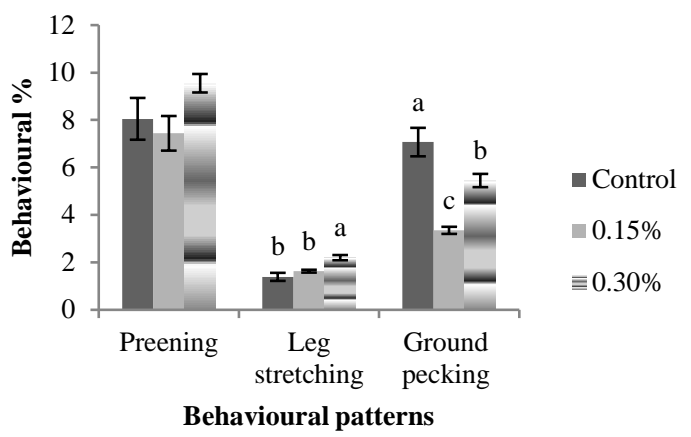

Figure 3. The effects of different prebiotic supplementation $(0,1.5$, and 3.0) on comfort and ground pecking behaviour activities of broiler ducks, (Means \pm SE represent the percentage activities of all birds per pen). ${ }^{a, b}$ Columns with no common superscript differ significantly $(P<0.05)$.

\subsection{Ground pecking behaviours}

Results presented in figure 3 , showed that both $1.5 \mathrm{~g} / \mathrm{kg}$ and $3.0 \mathrm{~g} / \mathrm{kg}$ prebiotic significantly decreased the ground pecking activities in comparison to control.

\section{Growth performance}

The effects of dietary supplementation of prebiotic on growth performance parameters are summarized in Table 3. Ducks supplemented with prebiotic had a higher body weight in comparison to the control group. However, the difference in body weight was not significant $(\mathrm{P}>0.05)$. The ducks fed on prebiotic at both levels $1.5 \mathrm{~g} / \mathrm{kg}$ and 3.0 $\mathrm{g} / \mathrm{kg}$ showed no significant $(\mathrm{P}>0.05)$ difference in weight gain, feed intake, feed conversion ratio (FCR), growth performance index and caloric conversion values as compared to control birds during the entire experimental period.

\section{Carcass characteristics}

The data in Table 4 showed that the relative weight of liver tended to be lower $(\mathrm{P}<0.05)$ for prebiotic fed birds $(1.84$ and $2.18 \%$ for 1.5 and $3.0 \mathrm{~g} / \mathrm{kg}$ prebiotic, respectively) than the control birds $(2.36 \%)$. The weight of thymus relative to the BW tended to be numerically higher for 
prebiotic groups $(0.70$ and $0.64 \%$ for 1.5 and $3.0 \mathrm{~g} / \mathrm{kg}$ prebiotic, respectively) compared with the control group $(0.56 \%)$. Also, the dressing percentage and total weight of gizzard, heart, spleen, and bursa remained unaffected by prebiotic dietary supplementation

Table 3. Effect of prebiotic supplementation $(0,1.5$, and $3.0 \mathrm{~g} / \mathrm{kg}$ ) on broiler duck performance during the experimental period from 15 to 60 days of age.

\begin{tabular}{|c|c|c|c|c|c|}
\hline \multirow[b]{2}{*}{ Item } & \multicolumn{3}{|c|}{ Prebiotic treatment } & \multirow[b]{2}{*}{ SEM } & \multirow[b]{2}{*}{$\mathrm{P}$} \\
\hline & $0 \mathrm{~g} / \mathrm{kg}$ & $1.5 \mathrm{~g} / \mathrm{kg}$ & $3.0 \mathrm{~g} / \mathrm{kg}$ & & \\
\hline \multicolumn{6}{|c|}{ Body weight (g): } \\
\hline Initial* & 217.19 & 239.19 & 240.00 & 14.98 & 0.7 \\
\hline $4 \mathrm{w}$ & 1052.81 & 1077.13 & 1098.75 & 15.14 & 0.4 \\
\hline $6 \mathrm{w}$ & 1910.31 & 1944.25 & 1970.94 & 13.31 & 0.2 \\
\hline $8 w$ & 2599.69 & 2643.25 & 2686.25 & 20.49 & 0.2 \\
\hline \multicolumn{6}{|c|}{ Weight gain (g): } \\
\hline $2-4 \mathrm{w}$ & 835.63 & 837.94 & 858.75 & 18.51 & 0.8 \\
\hline $4-6 \mathrm{w}$ & 857.50 & 867.13 & 872.19 & 22.23 & 0.9 \\
\hline $6-8 \mathrm{w}$ & 689.38 & 699.00 & 715.31 & 26.22 & 0.9 \\
\hline \multicolumn{5}{|c|}{ Feed intake (g/bird): } & \\
\hline $4-6 \mathrm{w}$ & $\begin{array}{l}1804.17 \\
2802.17\end{array}$ & $\begin{array}{l}176.69 \\
2764.89\end{array}$ & 2811.88 & $\begin{array}{l}18.07 \\
21.74\end{array}$ & 0.6 \\
\hline $6-8 w$ & 2815.31 & 2882.51 & 2911.94 & 21.25 & 0.1 \\
\hline \multicolumn{6}{|c|}{ Feed conversion ratio: } \\
\hline $2-4 \mathrm{w}$ & 2.17 & 2.15 & 2.07 & 0.05 & 0.7 \\
\hline $4-6 \mathrm{w}$ & 3.31 & 3.27 & 3.23 & 0.09 & 0.9 \\
\hline $6-8 w$ & 4.26 & 4.19 & 4.16 & 0.15 & 0.9 \\
\hline \multicolumn{6}{|c|}{ Performance index (\%): } \\
\hline $2-4 \mathrm{w}$ & 48.91 & 52.04 & 53.16 & 1.73 & 0.5 \\
\hline $4-6 \mathrm{w}$ & 58.45 & 61.13 & 61.17 & 1.62 & 0.7 \\
\hline $6-8 \mathrm{w}$ & 62.62 & 63.96 & 65.40 & 2.92 & 0.9 \\
\hline \multicolumn{6}{|c|}{ Caloric conversion ratio: } \\
\hline $2-4 \mathrm{w}$ & 6.50 & 6.45 & 6.21 & 0.16 & 0.7 \\
\hline $4-6 \mathrm{w}$ & 9.91 & 9.80 & 9.68 & 0.26 & 0.9 \\
\hline $6-8 \mathrm{w}$ & 12.74 & 12.53 & 12.44 & 0.44 & 0.9 \\
\hline
\end{tabular}

* Initial $=2$ weeks of age

Table 4. Effect of prebiotic supplementation $(0,1.5$, and $3.0 \mathrm{~g} / \mathrm{kg}$ ) on dressing and internal body organs in broiler duck during the experimental period from 15 to 60 days of age.

\begin{tabular}{|c|c|c|c|c|c|}
\hline \multirow[b]{2}{*}{ Item } & \multicolumn{3}{|c|}{ Prebiotic treatment } & \multirow[b]{2}{*}{ SEM } & \multirow[b]{2}{*}{$\mathrm{P}$} \\
\hline & $0 \mathrm{~g} / \mathrm{kg}$ & $1.5 \mathrm{~g} / \mathrm{kg}$ & $3.0 \mathrm{~g} / \mathrm{kg}$ & & \\
\hline Dressing \% & 73.05 & 73.04 & 73.16 & 1.01 & 0.998 \\
\hline Liver & $2.36^{\mathrm{a}}$ & $1.84^{\mathrm{c}}$ & $2.18^{\mathrm{b}}$ & 0.03 & 0.001 \\
\hline Gizzard & 2.94 & 3.29 & 3.15 & 0.06 & 0.099 \\
\hline Heart & 0.61 & 0.64 & 0.68 & 0.02 & 0.226 \\
\hline Spleen & 0.08 & 0.07 & 0.10 & 0.01 & 0.092 \\
\hline Thymus & 0.56 & 0.64 & 0.70 & 0.042 & 0.375 \\
\hline Bursa & 0.15 & 0.15 & 0.17 & 0.008 & 0.253 \\
\hline
\end{tabular}

\section{Blood metabolites}

The obtained results showed that the addition of prebiotic had no significant effect on total protein, albumin and globulin level (Table 5). The results also showed that adding prebiotic at $3.0 \mathrm{~g} / \mathrm{kg}$ level to duck diets significantly $(\mathrm{P}<0.05)$ decreased serum cholesterol.
Table 5. Effect of prebiotic supplementation $(0,1.5$, and $3.0 \mathrm{~g} / \mathrm{kg}$ ) on serum constituents in broiler duck during the experimental period from 15 to 60 days of age.

\begin{tabular}{|c|c|c|c|c|c|}
\hline \multirow[t]{2}{*}{ Item } & \multicolumn{3}{|c|}{ Prebiotic treatment } & \multirow[b]{2}{*}{ SEM } & \multirow[b]{2}{*}{$P$} \\
\hline & $0 \mathrm{~g} / \mathrm{kg}$ & $1.5 \mathrm{~g} / \mathrm{kg}$ & $3.0 \mathrm{~g} / \mathrm{kg}$ & & \\
\hline Total protein $\mathrm{g} / \mathrm{dl}$ & 4.59 & 4.26 & 4.68 & 0.23 & 0.743 \\
\hline Albumin g/dl & 1.99 & 1.92 & 1.81 & 0.07 & 0.576 \\
\hline Globulin g/dl & 2.60 & 2.33 & 2.86 & 0.22 & 0.626 \\
\hline Alb/Glob ratio & 1.22 & 0.87 & 0.64 & 0.11 & 0.097 \\
\hline Cholesterol mg/dl & $59.73^{\mathrm{a}}$ & $53.99^{\mathrm{ab}}$ & $44.15^{\mathrm{b}}$ & 1.77 & 0.006 \\
\hline
\end{tabular}

Means within the same row with different superscripts are significantly different $(\mathrm{P}<0.05)$.

\section{Avian influenza HI titer in Ducks}

The effect of prebiotic supplementation on the HI titer of Avian influenza vaccine are presented in Figure 4. There was a difference between treatment groups and control group. The average HI titer was 5.5 $\log ^{2}$ in control (Basal diet), $7.3 \log ^{2}$ and $8.25 \log 2$ in 1.5 and $3.0 \mathrm{~g} / \mathrm{kg}$ prebiotic treated groups, respectively.

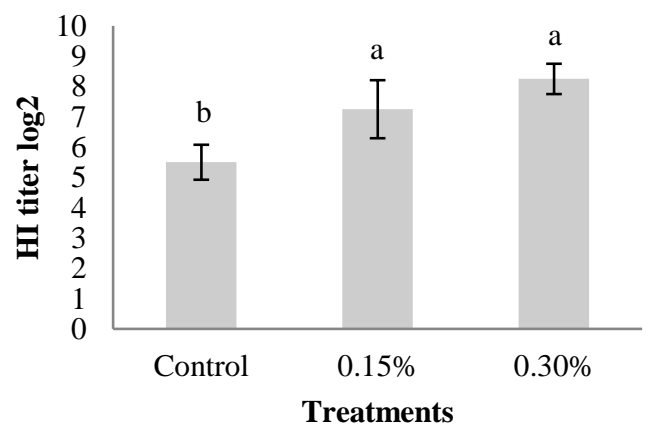

Figure 4. The effects of different prebiotic supplementation $(0,1.5$, and $3.0 \mathrm{~g} / \mathrm{kg})$ on $\mathrm{HI}$ titer at 60 thday old broiler ducks, (Means \pm SE). ${ }^{\text {a,b }}$ Columns with no common superscript differ significantly $(\mathrm{P}<0.05)$.

\section{The economy of broilers duck's production}

Table 6 clarified that the total production cost and total revenue were the highest (47.48 and 53.72 L.E, respectively) in treatment $3.0 \mathrm{~g} / \mathrm{kg}$ prebiotic and the lowest in treatment 1 (control group). Also, the lowest net revenue and economical feed efficiency (6.24 and 2.32 L.E, respectively) were found in the group fed on $3.0 \mathrm{~g} / \mathrm{kg}$ prebiotic, while the highest values $(6.48$ 
and 2.49 L.E, respectively) were found for the control group.

Table 6. An economic evaluation of the different experimental diets when adding prebiotic supplementation $(0,1.5$, and $3.0 \mathrm{~g} / \mathrm{kg})$ to broiler duck during the experimental period from 15 to 60 days of age.

\begin{tabular}{lccc}
\hline Item & \multicolumn{3}{c}{ prebiotic treatment } \\
\cline { 2 - 4 } & $0 \mathrm{~g} / \mathrm{kg}$ & $1.5 \mathrm{~g} / \mathrm{kg}$ & $3.0 \mathrm{~g} / \mathrm{kg}$ \\
\hline Average feed intake (kg/bird) & 5.562 & 5.665 & 5.756 \\
Price/kg feed (L.E) & 3.69 & 3.80 & 3.91 \\
Total feed cost (L.E) & 20.52 & 21.51 & 22.48 \\
Total production cost (L.E) & 45.52 & 46.51 & 47.48 \\
Body weight (kg/bird) & 2.600 & 2.643 & 2.69 \\
Price/kg body weight (L.E) & 20.00 & 20.00 & 20.00 \\
Total revenue (L.E) & 52.00 & 52.86 & 53.72 \\
Net revenue (L.E) & 6.48 & 6.35 & 6.24 \\
Economic feed efficiency (\%) & 2.49 & 2.40 & 2.32 \\
\hline
\end{tabular}

\section{Discussion}

In the current experiment, the results clarified that prebiotic dietary supplementation had induced several behavioural changes which could be endorsed to the enhancement of the birds' health status due to prebiotic immunestimulant and antioxidant characteristics (Koksal et al., 2013, Sadeghi et al., 2013, Mahmoud et al., 2017).

According to the author's knowledge, there are no available researches on the effect of MOS and $\beta$-glucans prebiotic on mobility activities and leg health of duck. The results from the current investigation indicated that $1.5 \mathrm{~g} / \mathrm{kg}$ of prebiotic dietary supplementation reduced the resting activities in comparison to the controls. Furthermore, $\quad 1.5 \mathrm{~g} / \mathrm{kg}$ prebiotic significantly increased the walking and standing activities of the birds in comparison to the control group. Similar results were recorded in broiler chicken exposed to heat stress by Mahmoud et al. (2017) who indicated that Agrimos dietary supplementation at $0.4 \%$ significantly reduced the resting activities in comparison to the controls. Likewise, they recorded that $0.05,0.2$ and $0.4 \%$ Agrimos dietary supplementation significantly expanded the walking activity of the birds in comparison to the control group. The current investigation hypothesized that MOS and $\beta$-glucans prebiotic may reduce the incidence of leg problems and increased walking activities due to its role in stimulating the immune system as well as its activity within the intestinal tract (lower $\mathrm{PH}$ and ammonia of the digest; effects on the intestinal pathogens and modify the bacterial fermentation) resulting in improvement of birds walking abilities. Supporting this suggestion Youssef (2011) reported that dietary supplementation of growing turkeys with $1 \%$ MOS tend to reduce the foot pad scores.

The data of the current investigation indicated that both 1.5 and $3.0 \mathrm{~g} / \mathrm{kg}$ prebiotic significantly increased the duck feeding activity than the control group, due to the positive effect of the prebiotic on the healthy digestive microflora of birds and the microbicide effect causing better utilisation of feed, and an improvement in the poultry health. On the contrary, Awad et al. (2009) and Wang et al. (2016) reported that MOS and $\beta$-glucans prebiotic inclusion had no beneficial effect on feed consumption in broiler chickens either exposed to stress condition or raised under the reasonable recommended environmental condition. Further, the current study results clarified that duck drinking activity was significantly increased by $3.0 \mathrm{~g} / \mathrm{kg}$ prebiotic group in comparison to the control group. Similarly, Mahmoud et al. (2017) reported that drinking activities of broiler chicken exposed to heat stress were significantly increased in $0.4 \%$ group compared to control and other treatments group. The increased water intake in birds supplemented with prebiotic may be attributed to the increase in feeding activities.

The current results showed that both 1.5 and $3.0 \mathrm{~g} / \mathrm{kg}$ prebiotic did not affect duck preening activities in comparison to control. On the contrary, in broiler chicken exposed to heat stress Mahmoud et al. (2017) reported that preening activities 
were increased in birds fed with $0.4 \%$. Regarding the leg stretching activities of ducks, the current results clarified that only $3.0 \mathrm{~g} / \mathrm{kg}$ prebiotic significantly increased the leg stretching exercises of ducks. Similarly, Mahmoud et al. (2017) indicated that $0.05,0.2$ and $0.4 \%$ Agrimos significantly increased the Wing and leg stretching activities of broiler chickens exposed to heat stress. This increase in leg stretching movements may reflect the improvement in the health status of the birds. Furthermore, using 1.5 and $3.0 \mathrm{~g} / \mathrm{kg}$ prebiotic significantly decreased the ground pecking activities in comparison to control. On the contrary, Mahmoud et al. (2017) indicated that dietary supplementation of Agrimos at doses of 0.05, 0.2 and $0.4 \%$ did not affect wall pecking activities in broiler chicken exposed to heat stress. In the current study, reduced ground pecking may be related to the increased feeding activities of duck. Regarding the differences between the current work results and Mahmoud et al. (2017), the different findings may be associated to several factors, such as the doses of prebiotic, age, and species of birds, and levels of stressors.

The current investigation is finding clarified that dietary supplementation of the diet with 1.5 and $3.0 \mathrm{~g} / \mathrm{kg} \mathrm{MOS}$ and $\beta$ glucans prebiotic not affect the performance indicators (body weight, weight gain, feed intake, growth performance index and caloric conversion values). The findings of Cengiz et al.(2012) could support these results and Koksal et al. (2013) who reported that MOS and $\beta$ glucans prebiotic insertion had no beneficial effect on growth rate and feed consumption in broiler chickens exposed to post-hatch holding time stress. Also, Iriyanti et al. (2018) reported that performance (live weight, body weight gain, and feed intake) of ducks were not significantly affected by Mannanoligosaccharide supplementation at $0.2 \%$ of the total feed.
These findings disagree with previous works done by Sohail et al. (2012) which revealed that dietary supplementation of MOS enhanced growth and decreased corticosterone concentrations in heat stressed broiler chickens. Similarly, Shendare et al. (2008) reported that insertion of $0.1 \%$ MOS and $\beta$ glucans prebiotic in the diet of broiler chickens raised under average environmental temperature significantly improved body weight gain and feed efficiency of birds as compared to the control diet. Despite the current investigation recorded that prebiotic induce a significant increase in feeding activities, there were no differences in feeding amount consumed by ducks. This difference may be attributed to the instantaneous scan sampling technique which used for recording behaviour as it only recorded the percentage of birds doing feeding activities and not calculating the actual feeding time or visiting number to the feeding trough.

The results of the present study indicated that prebiotic supplementation to the duck diet has a significant effect on the relative weight of liver. The beneficial effects of prebiotic on liver health are due to the positive changes in gut microflora. Controlling flora bacteria quantity can lead to minimized endotoxins production derived from bacteria such as ethanol and phenol which cause injury to the liver. Decreased levels of these compounds in the liver result in lowering of proinflammatory production such as Interleukin 6 and Tumor necrosis factor alpha via regulation of Nuclear factor kappa B. Also, they can lower urease activity of microflora bacteria followed by production of ammonia and liberate into the portal system. Furthermore, probiotic decreases the ammonia adsorption by reducing the fecal pH value (Javadi et al., 2017). On contrary Yalçin et al. (2014) reported that dietary 
supplementation with $0.1,0.2$ and $0.3 \%$ yeast cell wall (InteMos) not affect the relative weights of the liver in Ross 308 male broiler chicks raised under the average temperature. Also, Kalavathy et al. (2003), Chen et al. (2009), Mehrabadi and Jamshidi (2019) reported that prebiotic had no significant effect on liver weight.

The dressing percentage and relative of thymus, gizzard, heart, spleen, and bursa remained unaffected by dietary supplementation. These results are in agreement with previous research work which reported that dietary inclusion of prebiotics for broiler chicks did not affect the carcass yield percentage, hearts, proventriculus, gizzard, bursa and spleen weight (Abdel-Raheem and Abd-Allah 2011, Cengiz et al., 2012, Sarangi et al., 2016).

The found results proved that the insertion of prebiotic had no significant effect on total protein, albumin and globulin level. The results were by the findings of Mahmoud et al. (2017) who reported that supplementing broiler diet with prebiotic did not have any effect on total protein, albumin, and globulin. However, Helal et al. (2015) recorded that total serum protein increased in MOS supplemented group in comparison with the control one. Similarly, the current investigation results showed that adding prebiotic at $3.0 \mathrm{~g} / \mathrm{kg}$ level to duck diets significantly decreased serum cholesterol. This finding agrees with the earlier findings of Abdel-Raheem and Abd-Allah (2011) who stated that the concentration of serum cholesterol reduced considerably due to MOS supplementation. The lipid-lowering properties of prebiotics might be related to the changes in the intestinal bacterial flora composition, which ferments prebiotics to produce short-chain fatty acids in the gut and then causes a decrease in the systemic levels of blood lipids and cholesterol (Li et al., 2007). On the contrary, Yalcinkaya et al. (2008) noted that dietary inclusion of MOS to broilers diet could not significantly reduce the serum cholesterol.

The findings of the current investigation showed that prebiotic improves the immune responses in duck as it reflected by increased the HI titer of avian influenza vaccine. Similarly, Tohid et al. (2010) reported that the addition of MOS $(0.1,0.2$ and $0.3 \%)$ to the diet significantly increased antibody production against AIV in broiler chickens from 28 to 42 days of age. Supporting these results both Newman (1994) and Tohid et al. (2010) proposed that the increase of antibody titers in treated birds to the ability of oligosaccharides in the yeast cell wall to bind to viruses and work as an adjuvant of vaccines. It is already well-known that dietary supplementation of mannanoligosaccharide increased local mucosal IgA secretions; humoral and cell-mediated immune responses (Gómez-Verduzco et al., 2009) beta-glucans exposure increased interleukin-1 (IL-1) production as well as induced macrophage to proliferate. Dietary beta-glucans supplementation improved the macrophage phagocytic activity. Moreover, the primary and secondary lymphoid organs such as bursa of Fabricius, thymus, and spleen were larger in beta-glucanssupplemented chicks as compared to the chicks on a basal diet (Guo et al., 2003).

The total production cost and total revenue were highest (47.48 and 53.72 L.E, respectively) when using prebiotic at level $3.0 \mathrm{~g} / \mathrm{kg}$ compared to the control group. Furthermore, the lowest net revenue and economical feed efficiency (6.24 and 2.32 L.E, respectively) were found in the group fed on $3.0 \mathrm{~g} / \mathrm{kg}$ prebiotic, while the highest values (6.48 and 2.49 L.E, respectively) were found for the control group. These results are in contrast with Kamel and Mohamed (2016) who recorded that the economic efficiency measurement value was increased by prebiotic. 
Conclusion

In conclusion, the behavioural and physiological responses of duck to prebiotic supplementation are needed to be carefully considered to obtain maximal growth-promoting effects of prebiotic in duck production. Similarly, the results showed that dietary inclusion of prebiotics to duck diets did not significantly improve the growth performance and carcass traits as well as increase the cost of the ration.

\section{Acknowledgement}

We highly appreciate the farm staff for the care and management of the birds.

\section{Conflict of interest}

The authors reported no potential conflict of interest.

\section{References}

Abdel-Raheem S, Abd-Allah S (2011). The effect of single or combined dietary supplementation of mannan oligosacharide and probiotics on performance and slaughter characteristics of broilers. International Journal of Poultry Science, 10 (11): 854-862.

Ali A, Yilma J, De Haan N, Gebril O, Ettel $\mathrm{T}$, Negro-Calduch E, Lubroth $\mathrm{J}$ (2011). Poultry consumer needs and preferences in Egypt. A study report for FAO ECTAD.

Altmann J (1974). Observational study of behavior: sampling methods. Behaviour. 49(3-4):227266.

Awad W, Ghareeb K, Abdel-Raheem S, Böhm J (2009). Effects of dietary inclusion of probiotic and synbiotic on growth performance, organ weights, and intestinal histomorphology of broiler chickens. Poultry Science, 88(1): 49-56. DOI: 10.3382/ps.200800244.

Cengiz O, Koksal BH, Tatli O, Sevim O, Avci H, Epikmen T, Onol A (2012). Influence of dietary organic acid blend supplementation and interaction with delayed feed access after hatch on broiler growth performance and intestinal health. Veterinarni Medicina, 57: 515-528.

Chen K, Kho W, You S, Yeh R, Tang S (2009). Effects of Bacillus subtilis var. natto and Saccharomyces cerevisiae mixed fermented feed on the enhanced growth performance of broilers. Poultry Science, 88(2): 309-315.

El-sayed M, Mahrous U (2013). Influence of Overfeeding on Productive Performance Traits, Foie Gras Production, Blood Parameters, Internal Organs, Carcass Traits, and Mortality Rates in Two Breeds of Ducks. World Academic Science, Engineer and Technology. International Journal of Animal Veterinary Science, 7: 220226.

Gerzilov V, Bozakova N, Bochukov A, Penchev G, Lyutskanov M (2011). Influence of the prebiotic salgard and a herb mixture on pekin ducklings in organic poultry production: I. Growth performance and blood biochemical parameters. Biotechnology in Animal Husbandry, 27 (1): 33-43.

Gómez-Verduzco $\mathrm{G}$, Cortés-Cuevas A, Lòpez Coello C, Avila E, Nava G (2009). Dietary supplementation of mannan-oligosaccharide enhances neonatal immune responses in chickens during natural exposure to Eimeria spp. Acta Veterinaria Scandinavica, 51: 11-18.

Guo Y, Ali R, Qureshi M (2003). The influence of beta-glucan on immune responses in broiler chicks. Immunopharmacology and immunotoxicology, 25: 461-472.

Helal M, Youssef F, Moursi M, Khalil W, Abdel-Daim M (2015). The effectiveness of prebiotic as an alternative to the antimicrobial growth promoter on growth performance, blood constituents, intestinal healthiness and immunity of broilers. 
Alexandria Journal for Veterinary Sciences, 45: 13-25.

Hogerwerf L, Sidding A (2007). Ducks and HPAI H5N1 in the Nile Delta, Egypt. A Consultancy report for FAO.

Hong H, Kim C, Kim J, Seo J (2014). $\beta$ glucan reduces exercise-induced stress through downregulation of c-Fos and c-Jun expression in the brains of exhausted rats. Molecular Medicine Reports, 9:1660-1666.

Iriyanti N, Hartoyo B, Suhermiyati S (2018). Performance and intestinal profiles of tegal duck fed ration supplemented with prebiotics. Tropical Animal Science Journal, 41(1): 15-21.

Javadi L, Ghavami M, Khoshbaten M, Safaiyan A, Barzegari A, Gargari, BP (2017). The effect of probiotic and/or prebiotic on liver function tests in patients with nonalcoholic fatty liver disease: A double blind randomized clinical trial. Iranian Red Crescent Medical Journal, 19(4).

Kalavathy R, Abdullah N, Jalaludin S, Ho Y (2003). Effects of Lactobacillus cultures on growth performance, abdominal fat deposition, serum lipids and weight of organs of broiler chickens. British Poultry Science, 44: 139-144.

Kamel E, Mohamed L (2016). Effect of Dietary Supplementation of Probiotics, Prebiotics, Synbiotics, Organic Acids and Enzymes on Productive and Economic Efficiency of Broiler Chicks. Alexandria Journal for Veterinary Sciences, 50 (1): 93-96.

Klis F, Mol P, Hellingwerf $\mathrm{K}$, Brul S (2002). Dynamics of the cell wall structure in Saccharomyces cerevisiae. FEMS Microbiology Reviews, 26: 239-256

koksal BH, Cengiz O, Sevim O, Tatli O, Uner A (2013). Use of prebiotic supplementation to diet for reducing the negative effects of delayed feed access on growth rate in broiler chickens. International Journal of Poultry Science, 12 (12): 714-720.

Li XJ, Piao X, Kim S, Liu P, Wang L (2007).Effects of chitooligosaccharide supplementation on performance, nutrient digestibility and serum composition in broiler chickens. Poultry Science, 86 (6): 1107-1114.

Mahmoud UT, Abdel-Rahman M, Darwish M, Applegate T, Cheng H (2015). Behavioural changes and feathering score in heat stressed broiler chickens fed diets containing different levels of propolis. Applied Animal Behaviour Science, 166: 98-105.

Mahmoud UT, Elsayed M (2017). Behavioural and Physiological Effects of Mannan-oligosaccharide and $\beta$ glucan Prebiotic Combination on Heat Stressed Broiler Chickens. Journal of Advanced Veterinary Research, 7: 8186.

Mehrabadi M, Jamshidi R (2019). Effect of Antibiotic, Probiotic and Prebiotic in Diets Containing Barley on Performance, Digestibility, Intestinal Morphology, Blood Parameters and Immunological Response in Broilers. Iranian Journal of Applied Animal Science, 9(3): 497-507.

Newman k (1994). Mannan oligosaccharides: natural polymers with significant impact on the gastrointestinal microflora and the immune system. In Biotechnology in the Feed Industry. Proc. Alltech's 10th Ann. Symp. Nottingham University Press, Nottingham, UK, 167-175.

NRC, 1994. Nutrient Requirements of Poultry. National Academy Press, Washington, USA.

Sadeghi AA, Mohammadi A, Shawrang P, Aminafshar M (2013). Immune responses to dietary inclusion of prebiotic-based mannanoligosaccharide and $\beta$-glucan in broiler chicks challenged with Salmonella 
enteritidis. Turkish Journal of Veterinary and Animal Sciences, 37(2): 206-213.

Saluk J, Bijak M, Ponczek M, Nowak P, Wachowicz B (2013). (1- 3)- $\beta$-dGlucan reduces the damages caused by reactive oxygen species induced in human platelets by lipopolysaccharides. Carbohydrate Polymers, 97: 716-724.

Sarangi NR, Babu L, Kumar A, Pradhan C, Pati P (2016). Effect of dietary supplementation of prebiotic, probiotic, and synbiotic on growth performance and carcass characteristics of broiler chickens. The Veterinary World, 9(3): 313-319.

Shendare RC, Gongle M, Rajput A, Wanjari B, Mandlekar S (2008). Effect of supplementation of MannoOligosaccharide and b-glucans on maize based meal on commercial broilers. Veterinary World, 1: 13-15.

Sohail MU, Hume M, Byrd J, Nisbet D, Ijaz A (2012). Effect of supplementation of prebiotic mannan-oligosaccharides and probiotic mixture on growth performance of broilers subjected to chronic heat stress. Poultry Science, 91: 2235-2240.

Song JY, li W (2001). The preparation of mannan-oligosaccharide rom Saccharomyces cerevisiae and its effect on intestinal microflora in chicken. Journal of Zhejiang University (Agriculture and Life Science), 27: 447-450.

Tohid T, Hasan G, Alireza T (2010). Efficacy of mannan-oligosaccharides and humate on the immune response to Avian Influenza (H9) disease vaccination in broiler chickens. Veterinary Research Communication, 34: 709-717.

Uyeno Y, Shigemori $S$, Shimosato $T$ (2015). Effect of Probiotics / Prebiotics on Cattle Health and Productivity.
Microbes Environments, 30 (2): 126132.

Wang X, Farnel Y, Peebles E, Kiess A, Wamsley K (2016). Effects of prebiotics, probiotics, and their combination on growth performance, small intestine morphology, and resident Lactobacillus of male broilers. Poultry Science, 95(6): 1332-1340.

World Health Organization. (2002). The world health report 2002: reducing risks, promoting healthy life. World Health Organization.

Yalcin S, Yalcin S, Eser H, Şahin A, Yalçin S (2014). Effects of Dietary Yeast Cell Wall Supplementation on Performance, Carcass Characteristics, Antibody Production and Histopathological Changes in Broilers. Kafkas University Veteriner Fakültesi Dergisi, 20:757-764.

Yalçinkaya İ, Güngör T, Başalan M, Erdem E (2008). Mannan-oligosaccharides (MOS) from Saccharomyces cerevisiae in broilers effects on performance and blood biochemistry. Turkish Journal of Veterinary and Animal Science, 32 (1): 43-48.

Youssef GA, Ezzeldeen N, Mostafa A, Sherif N (2011). Effects of isolated lactobacillus acidophilus as a probiotic on chicken vaccinated and infected with salmonella typhimurium. Global Veterinaria, 7: 449-455. 